\title{
CONSIDERATIONS ON THE DEVELOPMENT OF MEDIATION IN ROMANIA L.D.Rath-Boșca
}

\author{
Laura-Dumitrana Rath - Boşca \\ Law and Economics Faculty, Social Sciences Department \\ Agora University of Oradea, Oradea, Romania \\ *Correspondence: Laura-Dumitrana Rath - Boşca, Agora University of Oradea, \\ 8 Piaţa Tineretului St., Oradea, Romania \\ E-mail: dumitra1970@yahoo.com
}

\begin{abstract}
Taking into consideration that our society faces a continuous development, it would be good that the principles and the methodes of managing the society would develope, because these seems to be overwhelmed.

Also, regarding the mediation, it takes time to implement it into the society's structure, in the social, economical and political sistem.
\end{abstract}

\section{Keywords: transition, law, mediation, measures, justice}

\section{Introduction}

The transition period in any society which encountered radical changes of the Government or the Political regime had multiple relativities and complications.

In Romania, the transition period seems to have no end and on the contrary it seems more and more complciated. The mediation is also in a transition period, that is also endless, after so many years, the concept is still very little known, very little understood and asimilated by the society and even by some mediators. This fact is not surprising because of the big number of mediators and the easy way of becoming a mediator. A mediator becomes a professional only by practising this job seriously, with perseverance and with vocation.

When we express our doubts regarding this situation, the explanation is that "it is a new system which has to model itself on the level of maturity of the Romanian society."

„The fact of being of the law is to achieve its goal of protecting the social values necessary for the rule of law state" 1 .

The first initiations for promoting the mediation were in 1996 when the Foundation for the Democratic Changes together with the Canadian International Institute for Applied Negociation started the first project in the mediation field. In this project were involved representatives of the legal system and representatives of the Ministry of Justice.

In 2000 The Ministry of Justice initiated the first project of law regarding the mediation. The project encountered a strong feeling of opposition, especially from the parliamentary who were also lawyers. The mediation, as an efficient solution for solving the legal cases and the conflicts between parties was not seen as one of the solutions for increasing the quality of the legal act and the relief of the Courts, even if it was included in the engagement of the Romanian's adhering to European Union.

At May $22^{\text {nd }}, 2006$ was published the Law no.192/2006 regarding the mediation and the profession of mediator which established that the mediation is part of the system for solving the conflicts, the duties of the mediator within the mediation procedure, the duties of

\footnotetext{
L. R. Popoviciu, Criminal Law. General part (Drept penal. Partea generală), Bucharest, Pro Universitaria Publishing House, 2011, page 36
} 
the Mediation Council, etc.

According to the Romanian law the civil, commercial, family, criminal conflicts can be subject of mediation and also the conflicts of the labour law. The mediation in the civil cases, when the case already started, the solving of the case by mediation may take part as the result of the parties' wish or as a recommendation of the Court, accepted by the parties.

In order to comply with the European norms and in order to respect the principle of primordial of the European law towards the law of the Member States, principle which had been based by the Court of Justice by the global interpretation of the legal norms it was necessary to make some changes of the Law no.192/2006.

In order to be able to respect the Directive 2008/52/CE of the European Parliament and of the Council regarding some aspects of mediation in civil and commercial field, Law no. 192/2006 was changed by Law no. 370/2009 and by OG no.13/2010 being included expressed disposals regarding the way in which the parties may execute the mediation act through the Public Notary or the Court.

The Directive 2008/52/CE of the European Parliament and the Council regarding some aspects of mediation in civil and commercial field reflects the objective established by the Community, that is the maintaining and development of the free space, security and justice within it, which assured the free movement of the persons. For the accomplish of this objective must have been adopted measures in the field of legal cooperation in the civil field, necessary for the good function of the inner market.

In order to facilitate the access to justice and according to the principle of the access to justice, the fundamental principle, the European Council requested to the member states, within the reunion from 15-16 October 1999 from Tampere, the creation of an alternative procedure, extra-judicial, and in April 2002, the Committee presented a green Book regarding the alternative methods for solving the cases in the civil and commercial field. After examining the situation at that moment, it had initiated a vast consultation with the member states and with the interested parties regarding the possible measures of encouraging the mediation.

The European Union had constantly promoted and encouraged the mediation as a way of alternative solution for the conflicts or trials, and by Directive 2008/52/CE it is requested the promotion and the use of mediation and to offer a clear frame of the justice to the parties who use mediation and also explains the necessity of including a legislation which deals especially with the essential aspects of the civil procedure. The Directive 2008/52/CE aimed the application of the mediation procedure in the over-border trials but it also showed that the member states should apply these disposals to the inner procedures, as well. ${ }^{2}$

The Directive 2008/52/CE explains that, mediation is a structured process, no matter how it is called or how it is related to, in which the parties try to get to an agreement, try to conclude an agreement, being assisted by an mediator. The process of mediation may take place at the initiative of the parties, may be recommended or imposed by the court or mentioned in the law of a member state. ${ }^{3}$

The Directive shows that the mediation should not be considered as an inferior solution to the judicial procedure because of the fact that the result depends exclusively on the parties. As a result, the member states should give an enforceable force to the parties' agreement.

If the agreement includes obligations which, by their nature, can't have a compulsory character or its clauses are against the law of one member stat, including the international private law, the member state must have the posibility to reject the acknowledgement of the

\footnotetext{
2 Directive 2008/52/CE of the European Parliament and Council shows that: „, no one shall prevent the member state to apply these provisions equally to the inner procedure of mediation.";

3 Art. 3 of the Directive 2008/52/CE of the European Parliament and Council regarding some aspects of mediation in the civil and commercial fields.
} 


\section{L.D.Rath-Boșca}

executory character of that agreement.

In the art. 12 of the Directive 2008/52/CE ,, The Transposition”, the member states had the duty to assure the entry into force of the law and of the administrative acts in order to comply to the disposals from the Directive until May 21, 2011, except of the art. 10, acording to which the compliance had to take place until November 21, 2010.

Article 10 from the Directive 2008/52/CE reffers to the authorities and competent Courts and shows that "Committee will make public by any means the informations regarding the competente courts or authorities according to art. 6 alin.3" 4; article that mentiones that, "The member states inform the Committee the name of the courts or of the competent authorities to receive the requests according to al.1 and 2"5.

In art. 6 alin 1 and 2 it is confirmed to the parties or to one of the parties the posibility to request the executory character of the content of the written ageement that resulted from the mediation, except of the case in which the content of the agreement is against the law of the member state in which the request is made or the law of that state doesn't show the posibility of offering a compulsory character. ${ }^{6}$ According to our law, there are two ways in which the mediation agreement receives the executory character, that is, by the means of the public notary or of the court.

This aspect results from the five main norms of the european act, such as: a) it impose to the member states the duty to encourage the preparation and training of the mediators so that in this way it is assured a mediation of good quality, b) gives to the judges the rights to recommend to the parties, when it is possible, to use first the mediation, c) it provides that, when the parties want, they may give their agreement an executory title, by the means of the court or the public notary, d) it is assured the privacy of the procedure; if there is a trial between the parties the mediator cannot give information regarding the mediation procedure, e) guarantees the freedom to access the Court after the mediation's procedure, the Court's deadline are suspended in the meantime.

The Law no. 202/2010 regarding the measures for accelerating the solving of the trials, the Little Reforme of Justice, ${ }^{7}$ establishes that the judge will try to reconcile the parties, giving them the necessary advices, according to law, so the judge will ask the parties to be present in front of the court, even if they are represented. Those cases which, according the law, can be the subject of mediation, the judge can invite the parties to take part to an informing meeting regarding the advantages of using this procedure. When he considers as necessary, taking into account the nature of the case, the judge will recommend to the parties to use mediation in order to solve their case, in any phase of the trial. The mediation is not compulsory for the parties.

If, according to al.1 and 2, the parties reconcile, the judge will include their reconciliation in the decision he will give ${ }^{8}$.

The Law no.115/2012 about the modification and the completion of Law no. 192/2006 regarding the mediation and the organisation of the profession of the mediator brings someting new at art.1 alin 1, that is, the obligation for the parties to participat at the informing meeting for solving through this way the conflicts in the civil, family fields and others. ${ }^{9}$

\footnotetext{
4 Art. 10 of the Directive 2008/52/CE of the European Parliament and Council regarding some aspects of mediation i the civil and commercial fields

5 Art. 6, alin 3 from the Directive 2008/52/CE

6 Art. 6, alin 1 from the Directive 2008/52/CE: , The Agreement may take the executory title by means of a decision from the Court ot he competent authority according to the memeber state's law in which the agreement was made."

7 Published in the Official Gazette of Romania, Part I, no. 714 from October 26th, 2010;

8 Art. 131 from Law 202/2010 regarding some measures for accelerating the solving of the trials. The littel reform of Justice: „, If, according to alin. 1 or 2 , the parties reconcile, the judge will include their reconciliation into the final decision."

9 Art. 2 (1) from Law no. 115/2012 for the modification and completion of Law no. 192/2006 regarding the mediation and the profession of mediator: , If law doesn't provede in other way, the persons or the companies, are obligated to participate to the meeting about the advantages of mediation, even after the registration of the request at the Courts, in order to solve the civil, family, criminal conflicts in this way.";
} 


\section{CONSIDERATIONS ON THE DEVELOPMENT OF MEDIATION IN ROMANIA}

During that meeting, it was presented to the parties the advantages and benefits that this way of solving the conflicts offers to them.

According to this law, the parties- persons or companies- were obliged to take part to the meeting of informing about the advatages pf the mediation procedure, even if the trial was opened, in order to solve in this way the conflicts in the civil, family and criminal fields and others, according to the law.

Article 2 alin. 1 from the Law are contrary to the previous provisions which showed that the persons and the companies should use the mediation procedure voluntarily, without imposing to anyone the way in which they should solve the cases and it is contrary to the provisions of art. 21 from the Romanian Constitution which says that none shall be prevented to go to Court when he/she considers that his/her right was broken and that anyone may go to Court in order to protect his/her rights, freedom and legal interests. Also, the fundamental law assures us that there shouldn't be any law that may limit this right. ${ }^{10}$ The free access to justice is recognised and guaranteed to each person and each one is free to go the the Courts to protect the rights that were broken or to accomplish their legal interests. The limitation of the access to justice has to be well-grounded.

In the European Court of the Human Rights' jurisprudence it is shown that: „The access to justice has to be provided effectively and efficiently."

Also, the Directive 2008/52/CE shows that mediation is a voluntary procedure and not an imposed one, the parties may initiate, organize or close it as they want at any moment. ${ }^{11}$

Art.3 lit.a) from the Directive defines the mediation as being an optional procedure, a trial in which the parties want to get to an agreement, ${ }^{12}$ that is the mediation is a possibility and not an obligation for the parties, not even regarding to the previous meeting for informing about the advantages of the mediation procedure.

The Directive 2008/52/CE shows at art. 5 „The use of mediation” that the judge has the possibility, after analysing the nature of the case, to reccomend to the parties to solve their case by using the mediation procedure. The Court may even invite the parties to take part to a meeting of informing about the advantages of the mediation. ${ }^{13}$

The Directive 2008/52/CE at art. 5 pct. $2^{14}$ is not contrary to the national law so far as the legal provisions which are going to be adopted, the parties will not be limited to access the justice and will not be punished or limited in any way in respect to this right.

Art. 2 from Law of mediation says that the Court will consider as inadmisible the request of the parties and it will be rejected, if the complainant didn't participat to the meeting of informing about the advantages of mediation, before recording the request or after opening the trial, before the first hearing. ${ }^{15}$

On May 2014 The Constitutional Court of Romania declared these provisions as unconstitutional, by Decision no.266/2014 regarding the exception of unconstitutionality of

\footnotetext{
10 Art. 21 from the Constitution of Romania:

(1) „Any person may go to Court in order to save his/her rights and freedoms or the legal interests.

(2) No other law shall limit this right;

(3) The parties have to right to an equal trial and to have their trial solved in a proper time."

11 The Preamble of the Directive 2008/52/CE of the European Parliament and Council from May 21st 2008 regarding the aspects of mediation in the civil and commercial fields, pulished in the Official Journal of the European Union series L no. 136 from May 24th 2008: "mediation shall be a voluntary procedure, that is the parties are themselves responsable for the procedure and may organise it as they want and close it in any moment.."

12 Art. 3 lit. a from the Directive 2008/52/CE: defines the mediation as being a process " in which two or more parties try, from theri own will, to get to an agreement regarding the solving of the trial between them (...)",

13 Art. 5 alin (1) „, Getting to mediation” Directive 2008/52/CE: „, a Court may, when it is necessary and taking into oconsideration the nature of the case, invite the parties to get to mediation in order to solve their case. The Court may, as well, invite the parties to take part to the meetings about the advantages of mediation , if that kind of meetings are organized and accesible.".

14 Art. 5 pct. 2 from the Directive 2008/52/CE: , This Directive doesn't brake the national legislation according to which mediation, before or after the beginning of the trial in the Court, is compulsory or it is subject of some penalties, as long as such a law doesn't limit the right of the parties to access the Court"

15 Art. 2 from the Law of mediation: ,, The Court will reject the request as inadmisible if the complainant didn't go the the meeting about the advantages of mediation before registring the request or after that moment but before the first hearing. (...)"
} 


\section{L.D.Rath-Boșca}

art. 200 from the Civil Code pf Procedure and art. 2 alin.1 and 1.2. and art. 60 from Law no.192/2006 regarding the mediation and the profession of mediator. ${ }^{16}$

The obligation of the parties to participate to the meetings about the avantages of mediation is an abuse, is a limitation of the freedom to justice, because none can impose to the parties the way in each they should solve their conflict, and by such a punishment- that of considering as inadmisible the request- the free access to justice is not only limited but forbidden.

Therefore, according to this legal act the session of informing about the advantages of mediation, before the registration of the request to the court, is no more compolsury, which means that the courts could no more reject the requests of those who didn't participate to those sessions. In conclusion, the participation at the session of informing becoms an voluntary option of the parties who are interested to use this procedure for solving the conflicts.

Although, mediation is a real way for realising the courts, unfortunately, the mediation and its principles are not assimilated by mediators, the mediation is not promoted as an independent multidisciplinary profession neither by the mediators nor by the Council of mediation which is independent identity with legal personality, of public interest and which actually has this duty. The mediation should be promoted also amoung the students from some Universities.

Besides, it is really neccesary that all the institutions and authorities, all those interested, to take serious measures in order to implement the mediation, starting with the information of the individuals and not only, continuing with their determination of using this way, this procedure of solving the conflicts.

\section{Conclusions}

This pioneer period of mediation's development in Romania, as it is called by many, should not be an excuse for non professional behaviour nad the legislative stuttering which I have presented above.

Also, I consider that it is necessary to bring into discution also the wrong understanding of some lawers who, by fear of „losing the market” have a negativ reaction both against the mediation and the mediators.

I consider that, when we feel that things go wrong we should say the truth by all means, we should not fe afraid of showing the minus and the inconsistency that slow the development of this beautiful profession, especially within an organised frame, that of the professional sessions.

\section{Bibliography}

L. R. Popoviciu, Criminal Law. General part (Drept penal. Partea generală), Bucharest, Pro Universitaria Publishing House;

Directive 2008/52/CE of the European Parliament and Councile regarding the aspects of mediation in the civil and commercial fields;

Law 202/2010 regarding some measures of accelerating the solving of trials. The little reform of justice;

Law 115/2012 for changing and completion of Law 192/2006 regarding mediation and the profession of mediator;

The Cosntitution of Romania;

The Official Gazette, Part I, no.464 from June 25th, 2014.

\footnotetext{
16 The official Gazette, Part I, no. 464 from June 25th, 2014.
} 